\title{
Ligninolytic enzymes in Basidiomycetes and their application in xenobiotics degradation
}

\author{
Mariya Brazkova ${ }^{1, *}$, Ralitza Koleva $^{2}$, Galena Angelova ${ }^{1}$ and Huseyin Yemendzhiev ${ }^{2}$ \\ ${ }^{1}$ Department of Biotechnology, University of Food Technologies, Plovdiv, Bulgaria \\ ${ }^{2}$ Department of Chemical Technologies, Asen Zlatarov University, Burgas, Bulgaria
}

\begin{abstract}
Variety of microorganisms have already proven their capabilities for degradation of wide range of wastes with anthropogenic nature. These pollutants, both liquid and solids, also include so called xenobiotics like phenol and its derivatives, PAHs, dyes, pesticides, pharmaceuticals, etc. Xenobiotics as bisphenol A (BPA), chlorhexidine (CHX), octenidine (OCT), other disinfectants and antiseptics have high ecotoxicological impact. Moreover, they can also impair our quality of life and our health interfering different metabolic and hormone receptors pathways in human body. Chemical treatment of such wastes is not a viable option because of its poor socio-economics and environmental merits. Therefore, applying effective, ecofriendly and cheap treatment methods is of great importance. Basidiomycetes are extensively investigated for their abilities to degrade numerous pollutants and xenobiotics. Through their extracellular ligninolytic enzymes they are capable of reducing or completely removing wide range of hazardous compounds. These enzymes can be categorized in two groups: oxidases (laccase) and peroxidases (manganese peroxidase, lignin peroxidase, versatile peroxidase). Due to the broad substrate specificity of the secreted enzymes Basidiomycetes can be applied as a powerful tool for bioremediation of diverse xenobiotics and recalcitrant compounds.
\end{abstract}

\section{Introduction}

Intensifying industrialization to meet all human's needs and the amount of annually produced toxic and persistent pollutants (or xenobiotics) is constantly increasing, with only $10 \%$ of organic pollutants being safely disposed [1]. As we know xenobiotics are synthetic compounds with applications for industrial, agricultural and domestic usage and they don't naturally occur in environment $[2,3$, 4]. Xenobiotics include phenols, polycyclic aromatic hydrocarbons (PAHs, personal care products (PCPs), pesticides, dyes, pulp and paper mills, pharmaceutical active compounds (PhACs) and other [3-14]. The intense usage results in their accumulation in the environment which inevitably is followed by different side effects regarding not only environmental security and safety but also impairing humans' health [15-17]. Different research teams proved that owing to their affinity to organic substances these toxicants can bioaccumulate in food chain causing numerous chronic diseases as respiratory infections, dysfunction of the nervous system, damage of the immune system, disruption of endocrine system, behavioral and development disorders, different teratogenic, carcinogenic and mutagenic effects [18-22].

Wide range of conventional techniques are applied and failed in xenobiotic treatment, due to the concomitant issues like high cost, toxic byproducts generation and waste disposal [2]. The most serious problem with conventional methods is that during degradation process the generated intermediates could be as toxic or even more toxic than the parent ones [2]. Biological treatment is considered to avoid this hazardous stage and it's accepted as clean eco-friendly, economically viable technique [1, 2, 23, 24]. Bioremediation is based on microorganisms' capability to utilize xenobiotics as carbon and nitrogen source without producing toxic byproducts [2, 25-28]. This is why bioremediation is amongst the most successful and effective environmental treatment technologies [29, 30].

Numerous microbial strains are tested through the years for their metabolic capabilities. Fungi are preferred for bioremediation due to their versatile metabolic activities [23]. They are equipped with mechanisms to convert hazardous pollutants with different nature into simple and non-toxic forms. Fungi can be applied to all kind of xenobiotic sources as aquatic and soil sites, and landfill leachates [1]. Furthermore, they are the only microorganisms on earth to decompose wood [23]. Owing to their tremendous potential to eliminate versatile xenobiotics, Basidiomycetes are subject of this review.

\section{Fungi in bioremediation and biodegradation}

Variety of anthropogenic pollutants are very persistent when disposed in the environment. For a long time,

\footnotetext{
* Corresponding author: mbrazkova@uft-plovdiv.bg
} 
scientists focused on their impact on both human health and organisms and on their biodegradability. It is of great importance that in the last years the society raises its awareness about these problems. There is a demand on new and clean technologies, and sustainable and ecofriendly packaging. There is also a huge necessity for cheap, clean and eco-friendly technique for treatment of the contaminated environment. Conventional treatment technologies are not effective in the case of xenobiotics so the attention is transferred to biological methods. Microorganisms are equipped with wide range of metabolic mechanisms which make them extremely effective in the processes of persistent toxicants degradation [8].

Bioremediation is the needed alternative and a solution to the environmental problems. This is a process of conversion of hazardous compounds into non-toxic simple forms via microbial (mostly fungal) metabolism. The ultimate goal of this process is full mineralization of persistent pollutants to $\mathrm{CO}_{2}, \mathrm{H}_{2} \mathrm{O}, \mathrm{N}_{2}$, etc. [24]. Fungi are proven to utilize xenobiotics as carbon and nitrogen source without producing toxic byproducts [2, 25-28]. They are preferred because of their ability to biodegrade toxicants resistant to bacteria [8]. This ability is due to their genetic diversity and functionality [2, 31-33], but also to the non-specific extracellular enzymes naturally targeting aromatic rings [8]. Basidiomycetes are suspected to have the ability to evolve and adapt under different conditions via transferring biodegradation metabolic genes [34, 35]. Another advantage over bacteria is that fungi can resist higher toxic concentrations [23].

There are evidences that fungi can degrade a wide spectrum of compounds and materials as starches, celluloses, biopolymers, pectins, fats, oils, chitin, wood/lignin, paper, cotton, linen, jute, etc. [23]. Lignin is the most complex biologically stable carbohydrate and the most abundant organic polymer on the earth [36]. It is known to be extremely resistant to microbial activities. This doesn't apply to Basidiomycetes. These particular fungi division is a model biodegrator with extremely wide range of hazardous and non-hazardous substrates. Most of the basidiomycetes are capable to degrade lignin which gives this subdivision the name white-rot fungi (after the bleached appearance of wood after lignin degradation) [36]. White-rot fungi (WRF) are common in nature and proven to successfully degrade also toxic antibiotics, PAHs, synthetic texite dyes, phenols, explosives, pesticides [1]. New reports demonstrated their potential to decompose even endocrine disruptive chemicals (EDC) like BPA and nonyphenol (NP) [37, 38]. Because of the extended use of the BPA substitute bisphenol S (BPS) the scientific community is now intensively studying it as well.

WRF are also known as ligninolytic fungi due to their unique enzyme secreting apparatus degrading aromatic rings of lignin [8]. Their degrading mechanism is advantageous because it's non-specific and based on free radical chain reactions [8, 36]. The secreted enzymes catalyze non-specific one-electron radical oxidation transforming wide range of organic pollutants. It is reported that xenobiotics degradation (especially dyes degradation) starts with formation of highly reactive free radical [39]. These free radicals add or remove electrons from the ground state of the compound. They can be generated at every moment and can cause chain reaction. Owing to the non-specific nature of the free radicals' chain reaction WRF are responsible for numerous toxicants degradation [39-41].

All we know for fungal bioremediation by now is due to some well-studied strains (Phanerochaete chrysosporium, Trametes versicolor, Ganoderma spp, Pleurotus ostreatus, Bjerkandera adusta, Irpex lacteus, Trichoderma reesei, Aspergilus niger, Trichoderma longibrachiatum etc.) [42]. According to recent estimates fungal biodiversity consists of up to 3.8 million species of which only about 3\% are described [43]. Exploring microbial communities in already contaminated sites can increase our knowledge of bioremediators and significantly improve environmental recovery processes [2].

\section{Ligninolytic enzymes}

Basidiomycetes are amongst the most if not the most spread fungi in nature. These fungi (WRF in particular) colonise mainly wood and secrete specific enzymes capable of degrading wood's constituents: extremely persistent and non-biodegradable lignin, cellulose and hemicellulose. These enzymes are called ligninmodifying enzymes (LME) but they are not responsible only for lignin-like structures degradation. After purification and/or immobilization they can be applied in different industries for eco-friendly, economical and nonpolluting waste treatment, including in food industry for clarification of juices, wines, etc. [44-46].

WRF secrete two main classes of enzymes: oxidases (laccase) and peroxidases (manganese peroxidase, lignin peroxidase and versatile peroxidase) [44, 47]. Despite WRF can, not all Basidiomycetes are able to produce the two types of enzymes. Some fungi can also express several isozymes. All enzymes are glycoproteins which increases their stability. Peroxidases contain heme group requiring hydrogen peroxide $\left(\mathrm{H}_{2} \mathrm{O}_{2}\right)$ for degradation. Lignin oxidation is not supplying energy to the WRF so secretion of enzymes is a result of secondary metabolism [47-49]. The starvation conditions actually stimulate the fungi to synthesize the lignonolytic enzymes. Different cultivation conditions favor different LME production. Cultivation parameters are of great importance because they can determine the enzyme activity. Parameters like temperature, $\mathrm{pH}$, and different ions affect enzyme stability and substrate specificity [50-53].

According to Ellouze and Sayadi (2016) laccase (Lac, EC 1.10.3.2.) is the most commonly occurring LME in nature degrading both phenolic and non-phenolic compounds [1]. Lac was reported for the first time by Yoshida in 1883. It is ubiquitous distributed in microorganisms, plants, insects [44, 47, 49, 54]. Microbial Lac has higher redox potential and wider substrate specificity which makes it more effective and preferred than plant Lac $[44,47,55]$. Amongst the most studied Lac producing WRF are Trametes versicolor, Phaneochaete chrysosporium, Pleurostus osreatus, 
Pleurostus eryngii, Trihoderma spp., etc. Fungi are capable of secreting two types of Lac: blue in submersed culture and yellow in solid-state fermentation. The difference between these laccases is that the blue one needs mediators to degrade non-phenolic compound, while the yellow doesn't [47]. Lac is copper containing biocatalyst oxidizing versatile contaminants via reduction of $\mathrm{O}_{2}$ to water [56]. It has four copper atoms per molecule classified into three copper centers: type 1 - blue $\mathrm{Cu}$ (T1, one $\mathrm{Cu}$ atom), type 2 - normal $\mathrm{Cu}(\mathrm{T} 2$, one $\mathrm{Cu}$ atom) and type 3 - coupled binuclear $\mathrm{Cu}$ (T3, two $\mathrm{Cu}$ atoms) [42, 44, 47]. This LME is part of the oxidases group which means that degradation mechanism includes transition of 4 electrons per catalytic cycle [49]. Lac biocatalytic activity is dependent on the redox potential of $\mathrm{T} 1$ copper active site (substrate-binding site) responsible for substrate oxidation [47]. T1 transfers one electron to the T2/T3 trinuclear cluster (inducer/inhibitor and oxygen binding site) [42], followed by reduction of one $\mathrm{O}_{2}$ molecule in the cluster releasing two molecules of water $[25,57,58]$. Lacs are preferred to peroxidases due to their ability to utilize atmospheric oxygen instead of $\mathrm{H}_{2} \mathrm{O}_{2}$ as an electron acceptor [44, 47]. The Lac degradation cycle includes full reduction followed by full oxidation of all four $\mathrm{Cu}$ ions [49].

Manganese peroxidase (MnP; EC 1.11.1.13) is reported as the most frequently secreted LME by nearly all WRF [49, 59]. It catalyzes the degradation of both phenolic and non-phenolic compounds, yet requires a second mediator for the latter [44, 47]. Furthermore, its activity is completely inhibited by $\mathrm{Hg}^{2+}, \mathrm{Pb}^{2+}, \mathrm{Ag}^{+}, \mathrm{NaN}_{3}$, lactate or ascorbic acid [60]. P. crysosporium was reported as the first basidiomycete to produce $\mathrm{MnP}$ in 1984. It is heme protein with an iron complex and multiple isoforms (11 secreted only by Ceriporiopsis subvermispora) $[47,49]$. MnP has $43 \%$ similar structure to LiP [47]. Its catalytic cycle is similar to other heme peroxidases with the exception that this is the only one with single-electron mechanism [44, 49, 58]. The oxidation of $\mathrm{Mn}^{2+}$ to $\mathrm{Mn}^{3+}$ runs in multiple steps. The cycle requires $\mathrm{H}_{2} \mathrm{O}_{2}$ to start with oxidation of the native enzyme heminic group. In this step is formed the first intermediate compound I containing $\mathrm{Fe}^{4+}$ oxo-porphyrin radical which oxidize one substrate molecule. Simultaneously, mono chelated $\mathrm{Mn}^{2+}$ is oxidized to $\mathrm{Mn}^{3+}$ resulting in transitional compound II, which in turn catalyze another electron separation and $\mathrm{Mn}^{3+}$ formation. The chelated $\mathrm{Mn}^{3+}$ oxidize phenolic rings reducing itself back into $\mathrm{Mn}^{2+}$. Native enzyme recovers its state by oxidation of $\mathrm{Mn}^{2+}$ to $\mathrm{Mn}^{3+}$ by compound II [42, 44, 47, 49].

Lignin peroxidase (LiP; EC 1.11.1.14) is hemecontaining glycoprotein employing $\mathrm{H}_{2} \mathrm{O}_{2}$ to breakdown lignin and lignin-like persistent xenobiotics [44]. It was originally discovered in P. chrysospoium [61] and later several isozymes were observed in T. versicolor [62], Pinus radiate [63], Phalaena sordiata [64], Phlebia tremellosa and Bjerkandera sp [47]. LiP differs from other peroxidases by its higher redox potential and low $\mathrm{pH}$ optimum [47, 49, 58, 61, 65]. Due to this specific of LiP mediators are not needed for toxicants decomposition and phenolic compounds are degraded with higher rate than non-phenolic [47]. The LiP degradation cycle can run in two- or multi-step reactions with only one electron extraction. Except for $\mathrm{H}_{2} \mathrm{O}_{2}$, veratryl alcohol (VA) is required as nonphenolic substrate electron donor [42, 49]. The native enzyme is oxidized to transitional compound I - $\mathrm{Fe}^{4+}$ radical which is further reduced by the xenobiotic to a transitional compound II. Alongside, xenobiotic is also transformed to a radical and reduces the enzyme to resting native form with subsequent xenobiotic radical formation (rate-limiting step) [42, 44]. In some cases, direct two-electron reduction san be employed for enzyme native state recovery [66].

Versatile peroxidase (VP; EC 1.11.16) as the name suggests is a hybrid peroxidase exhibiting cathalytic properties of both MnP and LiP. The only proven WRT to produce VP are Pleurotus sp. (originally observed) and Bjerkandera $\mathrm{sp}$. VP possess broad substrate specificity degrading both phenolic and non-phenolic compounds. Breakdown of phenolic compounds employs analogous mechanism as $\mathrm{MnP}$ - formation of $\mathrm{Fe}^{4+}$ radical and intermittent compounds in the presence of $\mathrm{H}_{2} \mathrm{O}_{2}$. In the case of non-phenolic compounds and lignin polymers VP adopts identical LiP mechanism [44, 47, 49].

LME are proven to be extremely efficient in vast spectrum of xenobitics degradation. Lac from $T$. versicolor and $P$. ostreatus was reported to accomplish 90-100\% removal of EDC (BPA and NP) in $6 \mathrm{~h}$ to 12 days $[38,67]$. Blanquez 2004 reached $80 \%$ decolorization with simultaneous $60 \%$ reduction in chemical oxygen demand (COD) by T. versicolor Lac [68]. Enzyme secreted from the same strain achieved complete decolorization of recalcitrant azo dyes as Amaranth, Tropaeolin O, Reactive Blue 15, Congo Red, and Reactive Black 5 and partial decomposition of Brilliant Red 3G-P, Brilliant Yellow 3B-A, and Remazol Brilliant Blue R [69]. Furthermore, Reactive Blue 15, Remazol Brilliant Blue R and Brilliant Red 3G-P decreased their toxic level after treatment. Three ring phenanthrene was degraded with minimum $76 \%$ effectiveness by Lac [70]. Lac was reported also to achieve the highest lignin removal of $81.67 \%$ in only $6 \mathrm{~h} \mathrm{[71].} \mathrm{Laccase} \mathrm{producing} \mathrm{WRF} \mathrm{are} \mathrm{well}$ positioned in food industry: they are successfully applied for treatment of tannin-containing waste water, distillery effluent and olive mill wastewater [72, 73]. Remazol Brilliant Blue $\mathrm{R}$ was discolored by Lac-LiP complex produced by fungus Marasmius cladophyllus [74]. Agrawal et al., reached more than 99\% degradation of phenanthrene and pyrene by Lac, LiP and MnP from Ganoderma lucidium [75]. MnP degraded 69\% NP in 150 $\min$ [76]. Combination of Lac and MnP decolorized up to $85 \%$ of Reactive blue 4 [77]. This enzyme complex secreted by Peniophora incarnate can degrade $86.5 \%$ phenanthrene, $82.6 \%$ pyrene and $77.4 \%$ fluoranthene [78]. MnP appears to be extremely effective in degradation of pesticides: it completely decomposes two toxic and mutagenic herbisides as 2,4-dichlorophenoxyacetic acid and 2,4,5-trichlorophenoxyacetic acid [79]; chlorine-containg susbstances as dioxins and their derivatives, dibenzofurans $[47,80]$. VP (including glucose oxidase) achieved full mineralization of NP in only $10 \mathrm{~min}$ [81]. 
Combination of LME is more effective in toxicants removal [38, 44]. Fungal enzymes are desired for biopulping and biobleacing [47]. They save energy, reduce the cooking time significantly, can be applied for soft and hardwoods, and biopupls have improved strength [82].

\section{Degradation of PAHs}

Polycyclic aromatic hydrocarbons (PAHs) are large group of diverse recalcitrant compounds with minimum two aromatic fused rings positioned linear, angular or clustered. They are generated through incomplete combustion or pyrolysis of oil, petroleum gas, coal and wood and are the most structurally diverse molecules in nature. Usually, compounds with less than six aromatic rings are regarded as small PAHs and those with more than six - large PAHs, and the increase of the number of the aromatic rings changes the physico-chemical characteristic of the substances. Industrialization is one of the major factors leading to PAHs constantly increasing concentration in the environment which represents a serious problem because these compounds are extremely stable, non-biodegradable, toxic, with mutagenic and carcinogenic activity and potential to bioaccumulate [83, 84]. The concern comes also from the immensely easy routes of exposure by being in contact with contaminated air, water, soil near waste sites [85-87]. On the other side, as the PAH molecular weight increases, so does their persistence towards biodegradation, bioaccumulation potential and hazardous effects, and their solubility in water and vapor pressure decreases. According to their bioavailability and desorption PAHs can be divided in three groups:

1) easily desorbing and available;

2) hardly desorbing and available; and

3) irreversible and completely unavailable [88].

Therefore, the desorption of these toxicants as a first step of the degradation process couldn't be a limiting factor for removal efficiency. The concern is that bioavailability and degradation rates are controlled and decreased by contact time [89-91].

Many conventional treatment methods are applied with poor efficiency. Fungal bioremediation or mycoremediation is considered as potent and viable option for PAHs decontamination. The ability of fungi to grow on xenobiotics and secrete LME for degradation of vast spectrum of contaminants makes them preferable than other microorganisms. Phanerochaete crysosporium, P. ostreatus, Bjerkandera adusta, $T$. versicolor, Aspergilus fumigatus, Penicillium chrysogenum, Irpex lacteus are amongst the proven PAHs degraders [92]. As we know that cultivation conditions are essential for microorfanism's growth and effectiveness [93]. The concentration of the pollutants (especially in case when higher PAHs are used as sole carbon source) can impair fungal growth, slowing down the remediation. Additional C-source supplement or optimization of incubation time could significantly increase the efficiency of fungi [94-96]. There are evidences for up to $98 \%$ PAHs decomposition after process optimization. Therefore, availability of carbon and nitrogen is crucial for enzyme activity and the use of PAHs as a growth substrate.

On the other hand, higher enzyme activity is not necessarily resulting in higher PAHs removal efficiency. This is in relevance with the reported by Schützendübel lack of $\mathrm{MnP}$ and LiP during Bjerkandera adusta application [97]. The data suggests new pathways for contaminant degradation and involvement of several systems and enzymes including but not limiting to the well-known LME. MnP and Lac are more active in PAHs degradation. Yellow Lac is preferred because blue one shows poor results even in mediator's presence. Irpex lacteus secreted $\mathrm{MnP}$ can oxidize three- and four- ring PAHs, whereas yellow Lac degraded three to five ring ones with efficiency of 40 to $100 \%$ [98-100]. Due to the higher redox potential and low $\mathrm{pH}$ optimum $\mathrm{LiP}$ degrades better non-phenolic compounds [47, 58, 61, 65]. It can be efficiently applied only to compounds with ionization potential $<8 \mathrm{eV}$ [101]. Regardless of the ongoing, in the last two decades, studies of PAHs degradation by fungi, the mechanisms used by the fungi for accomplishing this task are still not entirely clear.

\section{Degradation of EDC}

Endocrine-disrupting chemicals are extensive group of natural or chemically synthesized compounds with estrogen activity that can be divided into two subgroups: nonpersistent and persistent. Nonpersistent are quickly eliminated both from the environment and human body. Persistent EDC are not only stable in the recipient but they possess the ability to quickly biomagnify. Persistent EDC are uncharacteristic to all living organisms (both humans and animals) because they intrude endogenous hormones pathways causing variety of hormonal dysfunctions [102105]. They also can bind to specific nuclear receptors (peroxisome proliferator - activated receptors PPARs), thus affecting lipid metabolism and increasing the risk of obesity [106-108]. EDC disrupt the estrogenic balance in organism mainly targeting estrogenic receptors (ER $\alpha$ and ER $\beta$ ). They act as ERs antagonist or agonist via stimulation or inhibition of receptors ligands [109, 110].

Although the negative effects of these compounds are very well known, they remain widespread $[111,112]$. Not only production but just transportation of EDC-containing products can lead to contamination of environment. As with other xenobiotics, wastewater treatment plants (WWTP) cannot eliminate EDC despite having traceable amounts of ng/L [113-115].

The best known and used EDC is bisphenol A (BPA). It is amongst the most intensively manufacturing chemicals in the world [111]. From the thorough exploration of BPA is known that due to its resemblance to estradiol it can bind 1000 times easier to ERs and other receptors thus disrupting not only endocrine system but also causing oxidative stress to human cells $[116,117]$. Here is numerous evidence that BPA is also immune system disruptor with mutagenic and carcinogenic activity (induce prostate and mammary cancer) and obesity precursor. Being such a disruptor to numerous 
systems in human body, BPA usage in children's items is prohibited in European Union and USA [118-120].

Since the hazardous properties of BPA are acquaintance, a substitute is proposed - bisphenol $\mathrm{S}$ (BPS). Although its study has only recently begun, BPS's negative impact on human health is already well known $[108,121,122]$. Due to the abovementioned restrictions of BPA, BPS usage increased in the last years. Despite BPS is 37 times weaker than BPA it is still extremely harmful to human body with cytotoxic, immunotoxic, neurotoxic and even stronger genotoxic activity [123125].

Nolyphenol (NP) is another widely spread EDC. Due to its amphiphilic character, it is suitable for manufacturing of paints, hair dyes, pesticides, cosmetics, PVC pipes [49]. NP is less active than BPA and BPS but also is able to bind to ER inducing testosterone and spermatogenesis disruption in men and fetus related problems in pregnant women [107, 126, 127].

Along with discussed xenobiotics, WRF show huge EDC degrading capabilities, BPA and NP particularly $[38,128]$ For EDC breakdown can be applied both WRF and LME. Degradation of EDC by WRF and LME slightly differ. First step of the process employing WRF is sorption of the xenobitic to the fungal biomass due to the high surface to volume ratio of the WRF [129-131]. When LME was used sorption was not observed [132]. Nguen et al., reported maximum of $30 \%$ BPA sorption to inactivated Trametes versicolor [131]. Yonten et al., obtained $90 \%$ BPA elimination by sorption to immobilized Pleurotus eryngii [132]. This is a confirmation that immobilization favors biosorption as a treatment technique due to increased mechanical strength and reusability of the biosorbent. They also reported that after complete BPA saturation of the biosorbent the speed of the removal process slows down and remain constant. Despite this data, LME are proven to be the main WRF mechanism for EDC biodegradation [133, 134].

It is important to be mentioned that the environmental conditions affect the LME secretion. Parameters like temperature, $\mathrm{pH}$, heavy metals and ionic content influence the enzymes activity, stability and substrate specificity. If trigger factors aren't adequate the efficiency of EDC removal will be significantly lower [135-137].

Trametes versicolor and $P$. chrysosporium are among the most studied strains for EDC removal with efficiency of $80-100 \%[37,138]$. Unfortunately, the same percentage elimination cannot be repeated out of the lab. There are several known reasons for that: 1) natural microflora in the waterbodies interfere with the fungal degradation process [139]; 2) bacteria generates some compounds that hinder WRF growth [140, 141]; 3) bacteria again interfere with fungal growth competing for nutrients in the medium. Several solution strategies are tested with only short-term success [139, 141, 142]. The only viable solution is utilization of LME instead of whole fungal cells. Except for the wider range of environmental conditions, LME can more easily control the degradation process [143-145]. The issue with LME application is the production and purification cost of the enzymes as well as their reusability $[143,146]$. All these issues can be eliminated at once with enzyme immobilization [147,
148]. Despite possible decrease in the enzyme activity by immobilization, several researches reported high efficiency of EDC elimination: immobilized Lac reduced 85-100\% EDC [138, 146-148]; MnP efficiency was more than $95 \%[149,150]$; combination of LME reached $90 \%$ BPA elimination [143]. Generally, EDC removal with immobilized LME has potential due to the elimination results that can be the same or even better compared to the whole cell WRF.

\section{Degradation of synthetic dyes and textile industry effluents}

Coloring different kinds of materials with natural dyes is well known and practiced by humankind for millennia. In order to create wider ranges of colors, to make them more resistant to washing, etc., man started to synthesize new dyes since 1856 [151]. In additional attempt to improve their characteristics and make them resistant to detergents and other external factors synthetic dyes are modified by adding acidic and alkaline groups and metal ions [152]. However, this multiplies the water usage resulting in even bigger volumes of colored wastewater and more serious problems with different nature.

Synthetic dyes are unsaturated polyaromatic compounds soluble in water [34]. These dyes, despite considered recalcitrant xenobiotics, are applied in many industries including food, beverages, paper, cosmetics, etc. Assuredly, textile from all industries is mostly using synthetic dyes ( $65 \%$ of all dyes) with capacity of 10 to 20 mil tones of dyes, $15-50 \%$ of which ends in wastewater effluents [152-154].

Textile synthetic dyes are categorized in their own group in which azo dyes are dominant $[34,155]$. The azo bond $(-\mathrm{N}=\mathrm{N}-)$ makes them recalcitrant and nonbiodegradable naturally under aerobic conditions. They endanger not only human's health but also to the environment. High concentration of azo dyes can cause skin and mucous membrane ulcerations, respiratory tract irritation, nasal septum perforation, dermatitis, hemorrhage, diarrhea and vomiting. When released to surrounding waterbodies these dyes impair the quality of aquatic life, increase the chemical and biological oxygen demand (COD and BOD), reduce photosynthesis and favor toxicity $[156,157]$. The presence of the color reduces the oxygen levels and additionally hinders the treatment of these waters.

Physico-chemical treatment of such wastes is not a viable option because of its poor socio-economics and environmental merits. Despite their limitation as high cost and electricity consumption, various chemical compounds and sludge disposal [158] conventional treatment methods are still applied. Therefore, applying effective, eco-friendly and cheap treatment methods is of great importance. This niche is filled by microorganisms. There are numerous researches exploring bacteria and fungi since biodegradation is a very potent and sustainable alternative for synthetic dyes full mineralization [153, 159]. Due to the wide range substrate specifity of the fungal ligninolytic enzymes basidiomycetes are considered as cost effective and eco-friendly which makes 
them interesting for the scientific community. Typical for these microbes is their capability to produce less active sludge, to fully mineralize some xenobiotics and to not only degrade but detoxify synthetic dyes and their metabolites. This is essential because degradation not always equals detoxification [34, 152]. Decolorization duration usually depends on the nature of the microbial extract (crude or purified), cultivation conditions, microbial agent, dye, degradation conditions, etc.

As already discussed, Basidiomycetes eliminate synthetic dyes through specific enzyme production [34, 160]. They secrete enzymes like laccase, peroxidase, hydrogenase and azoreductase [39] which break down the recalcitrant azo bond. The already reduced into aromatic amines azo dyes are further mineralized to non-toxic metabolites which serve as an energy source for cells growth. As known azo dyes are not subject to biodegradation so a combined approach (aerobic and anaerobic) will be needed their efficient treatment [34]. Bioremediation by fungi (or mycoremediation) is favorited over bacteria because of the ability of fungi to grow on xenobiotics [161]. Another advantage of fungi over bacteria is that fungi can degrade both phenolic and non-phenolic dyes [34, 142].

The process of fungal dye elimination can occur in one (or several at a time) of the following three mechanisms: biosorption, bioaccumulation and biodegradation. Biosorption is an energy independent passive process of removing dyes and xenobiotics by their binding to the fungal biomass [34, 39]. Usually this is accomplished through mechanisms as adsorption, absorption, ion exchange, precipitation and surface complexation [162]. In the biosorption process both living and dead fungal biomass can be applied but owing to some advantages as reusability, easy storage, cost effectiveness, etc., dead cells are preferred. This is a two-phase process - a solid phase biosorbent/fungal biomass and liquid phase sorbate/dye solution [34]. The degree of biosorbent affinity to the sorbate is determining its distribution between the two phases. The biosorption process is influenced by factors as used microbes, size, ionic strength, concentration and dosage of the biosorbent. There are many examples of the application of fungal biomass as a synthetic dye sorbent including Aspergillus niger, A. oryzae, Rhizopus arrhizus, T. versicolor [163, 164].

Bioaccumulation is an energy and metabolically dependent active process of uptake and accumulation of xenobiotics in the cytoplasm of actively growing living cells. The usage of living cells makes bioaccumulation process less preferable than biosorption due to many reasons. Living cells are very sensitive to external factors like temperature, nutrients and supplements which can lead to increased chemical and biological oxygen demand levels. Some structural and biochemical properties of the biomass highly influence the process and high microbial cell density actually decrease the rate of accumulation [34]. Some of the proven bioaccumulating fungal strains are Candida tropicalis, Aspergillus niger, A. foetidus, even Saccharomyces cerevisiae can accumulate recalcitrant azo dyes [165].
Biodegradation, as bioaccumulation, is energy and metabolically dependent process of enzymatic breaking down the synthetic dye [39]. The most extensively used dye degrading enzymes are Lac, azoreductase, LiP and MnP. Both peroxidases adopt similar mechanism for dyes degradation. Laccase and azoreductase on the other hand, despite being oxidases, employ different degrading mechanism [34].

Peroxidases are family of low substrate specificity enzymes with a heme group $\left(\mathrm{Fe}^{3+}\right.$ and protoporphyrin IX complex) [34, 49, 166]. Both LiP and MnP employ $\mathrm{H}_{2} \mathrm{O}_{2}$ as a terminal electron acceptor for substrate oxidation. McMullan et al., reported that the process of sulfonated azo dyes degradation runs in two stages: first transition of the enzyme into its oxidized form by $\mathrm{H}_{2} \mathrm{O}_{2}$, then oxidizing the target dye [167]. The difference between the two peroxidases is that with the $\mathrm{MnP}$ there is an additional step after enzyme oxidation. While LiP directly oxidize the xenobiotic, MnP oxidize $\mathrm{Mn}^{2+}$ to $\mathrm{Mn}^{3+}$ and only then proceeds to oxidation of the dye [34].

Laccase as a member of the multi-copper oxidizing enzymes family adopts non-specific free radical mechanism to degrade xenobiotics as azo dyes [34]. Fungal laccase is a high-redox potential enzyme but this is not the only reason which makes it preferable to bacterial one and other enzymes. What favorites laccase to other oxidases is that it doesn't produce toxic amines degrading the dyes but phenolic compounds. Proven producers of highly efficient laccase are Trametes versicolor, T. villoa, Cladospora cladosporioides and Fusarium soloni [34, 169].

Individual enzymes decolorize synthetic dyes to varying degrees. The decolorization duration also varies depending on whether one or a combination of several enzymes is applied [34]. It is very important to be mentioned that textile waste waters are characterized with high temperatures which could be a serious factor in application of enzymes for bioremediation [152].

Despite all efforts, conventional physico-chemical methods are not potent enough to treat heavily colored waste waters from textile industry. Combined aerobic/anaerobic methods, as well as those with a consortium of bacteria and fungi, have been very successful. However, due to better efficiency, fungi are preferred over bacteria.

\section{Degradation of other xenobiotics}

Contemporary lifestyle demands increased industrialization which leads to high quality of life. Unfortunately, modernization and amenities simultaneously produce large amount of waste. Except for the well-known ones (as already discussed) another group of xenobiotics are also generated. This problem can be addressed in two major directions namely food insurance (agriculture and agrochemistry) and disinfection (of enormous importance in the past nearly 2 years).

Modern agriculture aims at maximum harvest and crops persistence in order to feed the constantly increasing population. Therefore, agrochemicals are mandatory in the pest control fight. More and more pesticides are used 
every year. Being in the top 3 of the worldwide most used herbicides atrazine is chosen as a case study [43]. It is extremely effective in the fight with broadleaf weeds in crops like sugarcane and maize, but as other halogenated aromatic compounds (including its derivatives) is regarded as toxic, carcinogenic and endocrine disruptor $[8,170,171]$. Due to its persistence (half-life of 41-231 days) atrazine remains in the soil and even ground water, negatively affecting environment, biodiversity and human health [170].

Bioremediation, as a strong environmental treatment tool, is studied for recovery of contaminated sites with different nature [171]. Bacterial removal of atrazine and complete catabolic pathways are extensively studied in the case of Pseudomonas strain ADP [43]. Fungal biodegradation is known to go through oxidativehydrolytic mechanisms having more and versatile metabolic pathways. It is known for years that atrazine fungal degradation runs in two stages: 1) molecule modification by removing the aromatic ring substitute $[171,172]$, and 2) breakdown of the aromatic ring. There are increasingly number of studies showing that the degree of atrazine elimination depends on availability of nutrients, nitrogen and mediators, which affect the biomass growth [24]. Henn et al., reported 32\% increase in atrazine removal only with $3 \mathrm{~g} / \mathrm{L}$ glucose supplement for biomass development [43]. Adding just $1 \mathrm{mM} \mathrm{HBT}$ (1-hydroxybenzotriazole) as a mediator increased biodegradation with $90 \%$ when Trametes versicolor was employed [173].

Despite the numerous reports of efficient xenobiotics removal in liquid medium, its known that fungi grow better on solid medium [43]. This is why Elgueta et al., studied atrazine bioremediation in solid matrix [174]. They observed $96 \%$ removal which gives a huge potential for success of other strains with reported 20-40\% degradation in liquid medium.

It is proved that nitrogen availability is beneficial for biomass development and thus for xenobiocs removal [175]. There are also some issues with catabolic repression in nitrogen rich medium in cases of ligninolytic enzymes implementation [176]. There is data of atrazine degradation in medium without enzymes, showing that the only factor controlling the degradation process is nitrogen availability [43]. It can be suggested that there is activity of unmeasured enzymes like chloroperoxidase, glyoxal oxidase, tyrosinases and haem-thiolate peroxygenases [171, 177]. Nitrogen presence exerts a different influence over different enzymes secreted in $\mathrm{N}$ rich or N-starving medium. This is very important in the case of cytochrome P450 enzymes which control detoxification of xenobiotics [175].

Usage of antiseptics and disinfectants is increasing every year $[8,177]$. Compounds containing in different antiseptics and products for dental hygiene have already been detected in domestic waste waters and their fate in the environment is still not defined. Some of the most used compounds are quaternary ammonium compounds QACs octenidine (OCT) and hexadecylpyridinium chloride (HDP); phenol derivatives (triclosan (TCS) and biguadines (chlorhexidine (CHX) [178, 179]. Unfortunately, the release of these kind of substances is not under control or restriction and their water solubility can cause serious pollution in very low concentrations $(p g-\mu \mathrm{g})[8]$. The practice has already shown that WWTP are not capable to eliminate these non-biodegradable micropollutants and they are released unmolested in the surrounding waterbodies $[180,181]$. The WWTP and the active sludge are not designed to process such toxicants. As a result, changes are observed both in the active sludge itself and in the microbial communities and sediments of the receiving waterbodies [182]. Despite the fact that OCT removal haven't been explored by know its stability and persistent are proven [183]. Alongside CHX and HDP it is a part of group of disinfectants with already defined antiestrogenic and/or anti endogenic activities [183].

A serious issue and a factor in dental care products degradation is that they are designed to eliminate microorganisms and to be non-biodegradable. For this reason, Linhartova et al., have conducted an in-depth study of biodegradation of dental hygiene products using two ligninolytic fungal strains - Pleurotus ostreatus and Irpex lacteus and compered their performance both in vivo and in vitro [8]. During the 21 days in vivo transformation tested strains removed $57 \%$ and $70 \% \mathrm{CHX}$ in liquid medium, for Pleurotus ostreatus and Irpex lacteus respectively. It was also accomplished 99-100\% recovery of CHX from both strains biomass. This result is another confirmation of the suggested sorption as a mechanism of elimination [181]. The reported removal of OCT was $48 \%$ and $35 \%$ for Irpex lacteus and Pleurotus ostreatus, respectively with $94 \%$ recovered. Again, biosorption is observed but due to the inability to recover the OCT from the biomass despite the efforts Linhartova et al., cannot be categorical for the elimination mechanism. Lygninolitic enzymes are detected both in in vivo and in vitro process - MnP for Irpex lacteus and Lac for Pleurotus ostreatus. In in vivo transformation the enzymes activity was observed to be 20 and about 4 times higher than in vitro for MnP and Lac, respectively.

Basidiomycetes are proven to efficiently degrade these type of xenobiotics. It is of great importance to define the metabolic pathways and products of the process.

Acknowledgements: This work was supported by the Bulgarian Ministry of Education and Science under the National Research Programme "Young scientists and postdoctoral students", approved by DCM \# 577/17.08.2018".

\section{References}

1. M. Ellouze, S. Sayadi, Management of Hazardous Wastes (IntechOpen, London, 2016)

2. S. Mishra, Z. Lin, S. Pang, W. Zhang, P. Bhatt, S. Chen, Front. Bioeng. Biotechnol. 9, 632059 (2021)

3. A. Embrandiri, S.K. Kiyasudeen, P.F. Rupani, M.H. Ibrahim, Plant Resp. Xenobiotic. 1 (2016)

4. S. Atashgahi, S.A. Shetty, S. Hauke, W.M. de Vos, Front. Physiol. 9, 888 (2018)

5. M. Tisma, B. Zelic, D. Vasic-Racki, Croat. J. Food Sci. Technol. 2, 34 (2010)

6. P. Baldrian, FEMS Microbiol. Rev. 30, 215 (2006) 
7. L. Levin, A. Viale, A. Forchiassin, Int. Biodeterior. Biodegrad. 52, 1 (2003)

8. L. Linhartova, K. Michalikova, K. Sredlova, T. Cajthaml, Molecules. 25, 400 (2020)

9. A. Paszczynski, R. Crawford, Soil Biochem. 10, 379 (2000)

10. G.D. Bending, M. Friloux, A. Walker, FEMS Microbiol. Letters. 212, 59 (2002)

11. P.C. Blanquez, N. Casas, X. Font, X. Gabarrell, M. Sarra, G. Caminal, T. Vicent, Water Res. 38, 2166 (2004)

12. S. Ben Younes, T. Mechichi, S. Sayadi, J. Appl. Microbiol. 102, 1033 (2007)

13. S. Ben Younes, Z. Bouallagui, S. Sayadi, J. Mol. Catal. B Enzym. 79, 41 (2012)

14. P. Blanquez, B. Guieysse, J. Hazard. Mater. 150, 459 (2008)

15. P. Dovrak, P.I. Nikel, J. Damborsky, V. de Lorenzo, Biotechnol. Adv. 35, 845 (2017)

16. M.A. Burgos-Aceves, A. Cohen, Y. Smith, C. Faggio, Ecotoxicol. Environ. Saf. 148, 995 (2018)

17. A.P. Ravindra, S.A. Haq, Smart Bioremediation Technologies : Microbial Enzymes (Elsevier, India, 2019)

18. A. Iovdijova, V. Bencko, Annl. Agric. Environ. Med. 17, 183 (2010)

19. P.K. Maurya, J. Ind. Poll. Control. 32, 580 (2016)

20. M. Sajid, C. Basheer, K. Narasimhan, A. Buhmeida, M.A. Qahtani, M.S. Al-Ahwal, Nat. Environ. Poll. Tech. 15, 733 (2015)

21. T.R. Catron, S. Gaballah, T. Tal, Curr. Pharmacol. Rep. 5, 468 (2019)

22. L.B. Bertotto, T.R. Catron, T. Tal, Neuro. Toxicol. 76, 235 (2020)

23. L. W. Perelo, J. Hazard. Mater. 177, 81 (2010)

24. A. Tomer, R. Singh, S.K. Singh, S.A. Dwivedi, C.U. Reddy, M.R.A. Keloth, R. Rachel. Mycoremediation and Environmental Sustainability (Springer, India, 2021)

25. Y.A.G. Mahmoud, Int. J. Environ. Tech. Sci. 3, 83 (2016)

26. P.K. Arora, A. Srivastava, S.K. Garg, V.P. Singh, Bioresour. Technol. 250, 902 (2018)

27. J.A. Siles, R. Margesin, Appl. Microbiol. Biotechnol. 102, 4409 (2018)

28. P. Bhatt, T. Joshi, K. Bhatt, W. Zhang, Y. Huang, S. Chen, J. Hazard. Mater. 409, 124927 (2020)

29. I.M.M. Gilliespie, J.C. Philp, Trends Biotechnol. 31, 329 (2013)

30. C.C. Azubuike, C.B. Chikere, G.C. Okpokwasili, World. J. Microbiol. Biotechnol. 32, 180 (2016)

31. F. Bastida, N. Jehmlich, K. Lima, B.E. Moris, H.H. Richnow, T. Hernandez, M. Bergen, C. Garcia, J. Proteomic. 135, 162 (2016)
32. P. Bhatt, A. Barh, In Silico Approach for Sustainable Agriculture (Springer, Singapore, 2018)

33. A.K. Dangi, B. Sharma, R.T. Hill, P. Shukla, Crit. Rev. Biotechnol. 39, 79 (2018)

34. B.S. Goud, H. L. Cha, G. Koyyada, J. H. Kim, Curr. Microbiol. 77, 3240 (2020)

35. S. Taghavi, T. Barac, B. Greenberg, B. Borremans, J. Vangronsveld, D. van der Lelie, Appl. Environ. Microbiol. 71, 8500 (2005)

36. C. Aarti, M. Valan Arasu, P. Agastian, South Indian J. Biol. Sci. 1(3), 119 (2015)

37. M. Llorca, M. Badia-Fabregat, S. Rodriguez-Mozaz, G. Caminal, T. Vicent, D. Barcelo. Chemosphere. 184, 1054 (2017)

38. Z. Kresinova, L. Linhartova, A. Filipova, M Ezechias, P Masin, T Cajthaml. New Biotechnol. 43, 53 (2018)

39. L. Singh, J. Appl. Biotechnol. Bioeng. 3(5), 430 (2017)

40. J.A. Bumpus, M. Tien, D. Wright, S. Aust. Science. 228, 1434 (1985)

41. J.S. Knapp, P.S. Newby, L.P. Reece. Enzyme Microbial. Technol. 17, 664 (1995)

42. A. Kumar, R. Chandra, Heliyon. 6, e03170 (2020)

43. C. Henn, D. A. Monteiro, M. Boscolo, R. da Silva, E. Gomes, BMC Microbiol. 20, 266 (2020)

44. M. Bilal, H.M N. Iqbal, Catal. Lett. 150, 524 (2020)

45. M. Asgher, M. Shahid, S. Kamal, H. M. N. Iqbal. J. Mol. Catal. B Enzym. 1, 56 (2014)

46. M. Bilal, Z. Nawaz, H. Iqbal, J. Hou, S. Mahboob, K. A. Al-Ghanim, H. Cheng, Prot. Peptide Lett. 25, 108 (2018)

47. S. Zainith, P. Chowdhary, S. Mani, S. Mishra, Microorganisms for Sustainable Environment and Health (Elsevier, India, 2020)

48. S. Yang, F.I. Hai, L.D. Nghiem, W.E. Price, F. Rodddick, M.T. Moreira, S.F. Magram, Bioresour. Technol. 141, 97 (2013)

49. A. Grelska, M. Noszczyńska, Environ. Sci. Pollut. Res. 27, 39958 (2020)

50. M.L. Niku-Paavola, E. Karhunen, A. Kantelinen, L. Viikari, T. Lundell, A. Hatakka, J. Biotechnol. 13, 211 (1990)

51. H.K. Mattila, M. Makinen, T. Lundell, Biotechnol. Biofuels. 13, 1 (2020)

52. M. Auriol, Y. Filali-Meknassi, R.D. Tyagi, C.D. Adams, Water Res. 41, 3281 (2007)

53. A. Kinnunen, P. Maijala, P. Jarvinen, A. Hatakka, Curr. Biotechnol. 6, 105 (2016)

54. H. Yoshida, J. Chem. Soc. 43, 472 (1883)

55. C.A. Gasser, E.M. Ammann, P. Shahagaldian, P.F. Corvini, Appl. Microbiol. Biotechnol. 98, 9931 (2014)

56. C.F. Thurston, Microbiology 140, 19 (1994) 
57. A.O. Falade, L.V. Mabinya, A.I. Okoh, U.U. Nwodo, Microbiol. Open. 7(6), e00722 (2018)

58. L. Pollegioni, F. Tonin, E. Rosini, FEBS J. 282, 1190 (2015)

59. M. Hofrichter, Enzym. Microb. Technol. 30, 454 (2002)

60. T. Manavalan, A. Manavalan, K. Heese, Curr. Microbiol. 70, 485 (2015)

61. M. Tien, T.K. Kirk, Methods Enzymol. 161, 238 (1988)

62. T. Johansson, K. G. Welinder, P.O. Nyman, Arch. Biochem. Biophys. 300, 57 (1993)

63. A.M. Moilanen, T. Lundell, T. Vares, A. Hatakka, Appl. Microbiol. Biotechnol. 45, 792 (1996)

64. T. Sugiura, K. Yamagishi, T. Kimura, T. Nishida, H. Kawagishi, H. Hirai, Biosci. Biotechnol. Biochem. 73, 1793 (2009)

65. T. Furukawa, F.O. Bello, all L. Hors, Front Biol. 9, 448 (2014)

66. L. Castro, L. Crawford, A. Mutengwa, J.P. Gotze, B. Michael, Org. Biomol. Chem. 14, 2385 (2016)

67. T. Brugnari, M. G. Pereira, G. A. Bubna, E. Freitas, A. Contado, R Correa, R. Castoldi, C. Souza, M. Polizeli, A. Bracht, R. Peralta, Sci. Total Environ. 634, 1346 (2018)

68. P. Blánquez, N. Casas, X. Font, X. Gabarrell, M. Sarrà, G. Caminal, T. Vicent, Water Res. 38, 2166 (2004)

69. J.A. Ramsay, T. Nguyen, Biotechnol. Lett. 24, 1757 (2002)

70. M.J. Han, H.T. Choi, H.G. Song, J. Microbiol. Seoul Korea. 42, 94 (2004)

71. R.C. Rajak, R. Banerjee. RSC Adv. 6, 61301 (2016)

72. S. Yagüe, M.C. Terrón, T. González, E. Zapico, P. Bocchini, G.C. Galletti, A.E. González, Rapid Commun. Mass. Spectrom. 14, 905 (2000)

73. T. González, M. C. Terrón, S. Yagüe, E. Zapico, G.C. Galletti, A. E. González, Rapid Commun. Mass. Spectrom. 14, 1417 (2000)

74. N. N. Sing, A. Husaini, A. Zulkharnain, H. Azman, BioMed Res. Int. 2017, 13257542017 (2017)

75. N. Agrawal, P. Verma, S. K. Shahi, Bioreour. Bioprocess. 5, 11 (2018)

76. M. Bilal, M. Asgher, H. M. N. Iqbal, H. Hu, X. Zhang, Environ. Sci. Pollut. Res. 24, 7035 (2017)

77. M. Steeve, A. Christiane, S.T. Jean-Bosco, N.M. Kor, D. Stephane, G. Philippe, Int. J. Curr. Microbiol. App. Sci. 3, 731 (2014)

78. H. Lee, S.Y. Yun, S. Jang, G.-H. Kim, J.-J. Kim, Bioremediat. J. 19, 1 (2015)

79. L. Pizzul, M. del Pilar Castillo, J. Stenström, Biodegradation. 20, 751 (2009)

80. N. Kasai, S. Ikushiro, R. Shinkyo, K. Yasuda, S. Hirosue, A. Arisawa, H. Ichinose, H. Wariishi, T.
Sakaki, Appl. Microbiol. Biotechnol. 86(2), 773 (2010)

81. R. Taboada-Puig, C. Junghanns, P. Demarche, M. Moriera, J. Lema, S. Agathos, Bioresour. Technol. 102, 6593 (2011)

82. J. Perez, J. Munoz-Dorado, T. D. L. R. De la Rubia, J. Martinez, Int. Microbiol. 5, 53 (2002)

83. A. K. Haritash, C.P. Kaushik, J. Hazard. Mater. 169, 1 (2009)

84. H. Cao, C. Wang, H. Liu, W. Jia, H. Sun, Sci. Rep. 10, $865(2020)$

85. A.P. Lei, Z.L. Hu, Y.S. Wong, N.F.Y. Tam, Bioresour. Technol. 98, 273 (2007)

86. C. Wang, H. Sun, H. Liu, B. Wang, J. Environ. Sci. (China). 26, 1135 (2014)

87. Z. Zhao, L. Zhang, Y. Cai, Y. Chen, Ecotoxicol. Environ. Saf. 104, 323 (2014)

88. J. Li, H. Sun, Y. Zhang, Soil Sediment Contam. 16, 79 (2007)

89. C. Wang, H. Sun, H. Liu, B. Wang, J. Environ. Sci. 26, 1135 (2014)

90. X. Li, P. Li, X. Lin, C. Zhang, Q. Li, Z. Gong, J. Hazard. Mater. 150, 21 (2008)

91. H. Sun, C. Wang, C. Huo, Z. Zhou, Environ. Toxicol. Chem. SETAC. 27, 103 (2008)

92. V. Balaji, P. Arulazhagan, P. Ebenezer, J. Environ. Biol. Environ. Biol. India. 35, 521 (2014)

93. G.O. Adams, P.T. Fufeyin, S.E. Okoro, I. Ehinomen, Int. J. Environ. Biorem. Biodegrad. 3, 28 (2015)

94. G. Zafra, A.E. Absalón, D.V. Cortés-Espinosa, Braz. J. Microbiol. 46, 937 (2015)

95. T. Drevinskas, R. Mickienè, A. Maruška, M. Stankevičius, N. Tiso, J. Mikašauskaite, O. Ragažinskienè, D. Levišauskas, V. Bartkuvienè, V. Snieškienè, A. Stankevičienè, C. Polcaro, E. Galli, E. Donati, T. Tekorius, O. Kornyšova, V. Kaškonienè, Anal. Bioanal. Chem. 408, 1043 (2016)

96. G. Zafra, A. Moreno-Montaño, Á.E. Absalón, D.V. Cortés-Espinosa, Environ. Sci. Pollut. Res. 22, 1034 (2015)

97. A. Schützendübel, A. Majcherczyk, C. Johannes, A. Hüttermann, Int. Biodeterior. Biodegrad. 43, 93 (1999)

98. N.N. Pozdnyakova, Biotechnol. Res. Int. 2012, e243217 (2012)

99. N.N. Pozdnyakova, J. Rodakiewicz-Nowak, O.V. Turkovskaya, J. Haber, Enzym. Microb. Technol. 39, 1242 (2006)

100.N.N. Pozdnyakova, J. Rodakiewicz-Nowak, O.V. Turkovskaya, J. Haber, J. Mol. Catal. B Enzym. 41, 8 (2006)

101.E. Torres, R. Tinoco, R. Vazquez-Duhalt, Water Sci. Technol. 36, 37 (1997)

102.T. Cajthaml, Environ. Microbiol. 17, 4822 (2015) 
103.W. Nelson, D.Y. Liu, Y. Yang, Z.H. Zhong, Y.X. Wang, Y.B. Ding. Biol. Reprod. 102, 276 (2020)

104.A. Gore, V. Chappell, S. Fenton, J. Flaws, A. Nadal, G. Prins, J. Toppari, R. Zoeller, Endocr. Rev. 36, 593 (2015)

105.R. Lauretta, A. Sansone, M. Sansone, F. Romanelli, M. Appetecchia, Front Endocrinol. 10, 1 (2019)

106.S. Agarwal, A. Yadav, R.K. Chaturvedi, Biochem. Biophys. Res. Commun. 483, 1166 (2017)

107.P. Urriola-Muñoz, R. Lagos-Cabré, R.D. Moreno, PLoS One. 9, 1 (2014)

108.P. Gupta, A. Pushkala, Cell Tissue Res. 19, 6829 (2019)

109. J.A. Rogers, L. Metz, V.W. Yong. Mol. Immunol. 53, 421-430 (2013)

110. S. Sifakis, V.P. Androutsopoulos, A.M. Tsatsakis, D.A. Spandidos, Environ. Toxicol. Pharmacol. 51, 56 (2017)

111. M. Noszczyńska, Z. Piotrowska-Seget, Chemosphere. 201, 214 (2018)

112. M, Rodríguez-Peña, C.E. Barrera-Díaz, B.A. Frontana-Uribe, G. Roa-Morales, Int. J. Electrochem. Sci. 14, 4409 (2019)

113. S. M. Ruel, M. Esperanza, J.M. Choubert I. Valor, H. Budzinski, M. Coquery, Water Sci. Technol. 62, 2970 (2010)

114. E.K. Radwan, M.B.M. Ibrahim, A. Adel, M. Farouk, Environ. Sci. Pollut. Res. 27, 1776 (2020)

115. X. Bai, K. Acharya, Environ. Pollut. 247, 534 (2019)

116. F.S. Vom Saal, C. Hughes, Environ. Health Perspect. 113, 926 (2005)

117. X. Li, P. Yin, L. Zhao, Food Chem. Toxicol. 105, 73 (2017)

118. W. Wu, M. Li, A. Liu, C. Wu, D. Li, Q. Deng, B. Zhang, J. Du, X. Gao, Y. Hong, Dose-Response. 18, $1(2020)$

119. S.M. Ho, R. Rao, S. To, E. Schoch, P. Tarapore, Endocr. Relat. Cancer. 24, 83 (2017)

120. K. Wiersielis, B. Samuels, T. Roepke, Pharmacol. Res. 155, 104743 (2020)

121. D. Wu, Q. Feng, T. Xu, A. Wei, H. Fong, Chem. Eng. J. 331, 517 (2018)

122. W. Qiu, M. Yang, S. Liu, P. Lei, L. Hu, B. Chen, M. Wu, K.J. Wang, Environ. Sci. Technol. 52, 831 (2018)

123. ECHA, Bisphenol S registration(Eur. Chem. Agency, Helsinki, 2020)

124. Z. Lin, X. Zhang, F. Zhao, S. Ru, Toxicol. Appl. Pharmacol. 366, 75 (2019)

125. P. Song, K. Fan, X. Tian, J. Wen, Toxicol. in Vitro. 54, 224 (2019)

126. Z. Noorimotlagh, N.J. Haghighi, M. Ahmadimoghadam, F. Rahim, Environ. Sci. Pollut. Res. 24, 3298 (2017)
127. H.A.A. Aly, Ò. Domènech, Z.M. Banjar, Toxicol. Appl. Pharmacol. 261, 134 (2012)

128. T. Saito, K. Kato, Y. Yokogawa, M. Nishida, N. Yamashita, J. Biosci. Bioeng. 98, 64 (2004)

129. S. Zafar, F. Aqil, I. Ahmad, Bioresour. Technol. 98, 2557 (2007)

130. J. Ding, B.L. Chen, L.Z. Zhu, Chin. Sci. Bull. 58, $613(2013)$

131. L.N. Nguyen, F.I. Hai, S. Yang, J. Kang, F. Leusch, F. Roddick, W. Price, L.D. Nghiem, Int. Biodeterior. Biodegrad. 88, 169 (2014)

132. V. Yonten, M. Ince, M. Tanyol, N. Yildirim, Desalin. Water. Treat. 57, 22362 (2016)

133. J. Wang, R. Yamamoto, Y. Yamamoto, T. Tokumoto, J. Dong, P. Thomas, H. Hirai, H. Kawagishi, Chemosphere 93, 1419 (2013)

134. L. Haroune, S. Saibi, H. Cabana, J.P. Bellenger, Environ. Sci. Technol. 51, 897 (2017)

135. T. Suetomi, T. Sakamoto, Y. Tokunaga, T. Kameyama, Y. Honda, H. Kamitsuji, I. Kameshita, K. Izumitsu, K. Suzuki, T. Irie, Curr. Genet. 61, 127 (2015)

136. P. Daly, M. Peng, S. Casado López A. Lipzen, V. Ng, V. Singan, M. Wang, I. Grigoriev, R. Vries, M. Makela, J. Biotechnol. 309, 142 (2020)

137. G. Janusz, K.H. Kucharzyk, A. Pawlik, M. Staszczaka, A.J. Paszczynski, Enzyme Microbial. Technol. 52, 1 (2013)

138. M. Brazkova, G. Angelova, A. Krastanov, J. Microbiol. Biotechnol. Food Sci. 9 (2), 204 (2019)

139. K. Svobodová, Č. Novotný, Appl. Microbiol. Biotechnol. 102, 39 (2018)

140. H. Valkova, C. Novotny, K. Malachova, P. Slosarcikova, J. Fojtik, Sci. Total. Environ. 584585, 1114 (2017)

141. J.A. Mir-Tutusaus, R. Baccar, G. Caminal, M. Sarrà, Water Res. 138, 137 (2018)

142. J.A. Libra, M. Borchert, S. Banit, Biotechnol. Bioeng. 82, 736 (2003)

143. F. Gassara, S.K. Brar, M. Verma, R.D. Tyagi, Chemosphere. 92, 1356 (2013)

144. D. Becker, S. Rodriguez-Mozaz, S. Insa, R. Schoevaart, D. Barcelo, M. de Cazes, M-P. Belleville, J. Sanchez-Marcano, A. Misovic, J. Oehlmann, M. Wagner, Org. Process Res. Dev. 21, 480 (2017)

145. A.O. Falade, U.U. Nwodo, B.C. Iweriebor, E. Green, L.V. Mabinya, A.I. Okoh, Microbiologyopen. 6, 1 (2017)

146. S. Voběrková, V. Solčány, M. Vršanská, V. Adam, Chemosphere. 202, 694 (2018)

147. D. Boer, MSc thesis (2018)

148.J. Zdarta, K. Antecka, R. Frankowski, A. ZgołaGrześkowiak, H. Ehrlich, T. Jesionowski, Sci. Total. Environ. 615, 784 (2018) 
149. R. Taboada-Puig, C. Junghanns, P. Demarche, M.T. Moreira, G. Feijoo, J.M. Lema, S.N. Agathos, Bioresour. Technol. 102, 6593 (2011)

150. M. Bilal, M. Asgher, R. Parra-Saldivar, H. Hu, W. Wang, X. Zhang, H.M.N. Iqbal, Sci. Total. Environ. 576, 646 (2017)

151.W.H. Perkin, Producing a new colouring matter for the dyeing with a lilac or purple color stuffs of silk, cotton, wool, or other materials (United Kingdom, Patent No. 1984, AD 1856)

152.J.D. Sosa-Martinez, N. Balagurusamy, J. Montanez, R.A. Peralta, R.F.P.M. Moreira, A. Bracht, R.M. Peralta, L. Morales-Oyervides, J. Hazard. Mater. 400, 123254 (2020)

153. S. Sarkar, A. Banerjee, U. Halder, R. Biswas, R. Bandopadhyay, Water Conserv. Sci. Eng. 2, 121 (2017)

154. H.B. Mansour, I. Houas, F. Montassar, K. Ghedira, D. Barillier, R. Mosrati, L. Chekir-Ghedira, Environ. Sci. Pollut. Res. 19, 2634 (2012)

155. I. Sghaier, M. Guembri, H. Chouchane, J. Text. Eng. Fashion Technol. 5, 134 (2019)

156. K. Rehman, T. Shahzad, A. Sahar, S. Hussain, F. Mahmood, M.H. Siddique, Peer J. 6: e4802 (2018)

157. B. Lellis, C.Z. Favaro-Polonio, J.A. Pamphile, J.C. Polonio, Biotechnol. Res. Innov. 3, 275 (2019)

158. J.M.S. Oliveira, M.R. de Lima e Silva, C.G. Issa, J.J. Corbi, M.H.R.Z. Damianovic, E. Foresti, J. Hazard. Mater. 385, 121558 (2020)

159. M. Sudha, A. Saranya, G. Selvakumar, N. Sivakumar, Int. J. Curr. Microbiol. Appl. Sci. 3, 670 (2014)

160. S Mishra, A Maiti, Clean Technol. Environ. Policy. 21, 763 (2019)

161. S.K. Garg, M. Tripathi, Res. J. Microbiol. 12, 1 (2017)

162. G.M. Gadd, J. Chem. Technol. Biotechnol. 84, 13 (2009)

163. N. Ahalya, T. Ramachandra, R. Kanamadi, Res. J. Chem. Environ. 7, 71 (2003)

164. M. Takey, T. Shaikh, N. Mane, D. Majumder, Int. J. Res. Eng. Technol. 3, 565 (2014)

165. Z. Aksu, G. Donmez, Process. Biochem. 40, 2443 (2005)

166. Q. Husain, Rev. Environ. Sci. Bio/Technol. 9, 117 (2010)

167. G. McMullan, C. Meehan, A. Conneely, N. Kirby, T, Robinson, P. Nigam, I. Banat, R. Marchant, W. Smith, Appl. Microbiol. Biotechnol. 56, 81 (2001)

168. D.M. Mate, M. Alcalde. Biotechnol. Adv. 33, 25 (2015)

169. S. Singh, V. Kumar, A. Chauhan, S. Datta, A. Wani, N. Singh, J. Singh, Environ. Chem. Lett. 16, 211 (2018)
170. H. Harms, D. Schlosser, L.Y. Wick. Nat. Rev. Microbiol. 9, 177 (2011)

171. M.P. Serbent, D.K.S. Guimarães, E.R. DrechslerSantos, E.R. Drecher-Santos, C.V. Helm, A. Giongo, L.B.B. Tavares. Int. J. Environ. Sci. Technol. 17, 2995 (2020)

172. L.N. Nguyen, F.I. Hai, S. Yang, J. Kang, F.D.L. Leusch, F. Roddick, W.E. Price, L.D. Nghiem. Int. Biodeterior. Biodegrad. 88, 169 (2014)

173. S. Elgueta, C. Santos, N. Lima, M.C. Diez, Arch. Agron. Soil Sci. 62, 1451 (2016)

174. A.K.S. Kameshwar, W. Qin, Curr. Genet. 63, 877 (2017)

175. J.A. Buswell, Y. Cai, S. Chang, FEMS Microbiol. Lett. 128, 81 (1995)

176. P. Xiao, P. Mori, I. Kamei, H. Kiyota, K. Takagi, R. Kondo, Chemosphere. 85, 218 (2011)

177. M. Ostman, R.H. Lindberg, J. Fick, E. Bjorn, M. Tysklind, Water Res. 115, 318 (2017)

178. M. Cesen, D. Heath, M. Krivec, J. Kosmrlj, T. Kosjek, Environ. Pollut. 242, 143 (2018)

179. C. Zhang, F. Cui, G.M. Zeng, M. Jiang, Z-Z. Yang, Z-G. Yu, M-Y. Zhu, L-Q. Shen, Sci. Total Environ. 518, 352 (2015)

180. M.S. Fortunato, S. Baroni, A.J. Gonzalez, J.D.A. Roncancio, M. Papalia, M. Martinefsky, V. Tripodi, E.Planes, A. Gallego, S.E. Korol, Water Air Soil Pollut. 229, 120 (2018)

181. J.R. Lawrence, B. Zhu, G.D.W. Swerhone, E. Topp, J. Roy, L.I. Wassenaar, T. Rema, D.R. Korber, Appl. Environ. Microb. 74, 3541 (2008)

182. T.P. Keerthisinghe, L.N. Nguyen, E.E. Kwon, S. Oh, J. Environ. Manag. 237, 629 (2019)

183. K. Michalíková, L. Linhartová, M. Ezechiáš, T. Cajthaml, Chemosphere. 217, 534 (2019) 